\title{
Assessment of Needs Satisfaction of Displaced Persons with Intervention by Emergency Management Agency (SEMA), Borno State, Nigeria
}

\author{
Aminchi Daniel, Ya'ajiram Babakura Imam
}

\begin{abstract}
The study assessment the needs satisfaction of displace persons with Intervention by Emergency Management Agency (SEMA), Borno State, Nigeria. The objectives of the study are to assess the extent of internally displaced persons' physiological needs, satisfaction, and assess the level of internally displaced persons' safety and security needs satisfaction, with interventions by SEMA in Dalori Camp 1 in Borno state. For the purpose of this study, the following research question were made: What is the extent of IDPs' physiological needs satisfaction with interventions by SEMA in Dalori IDPs Camp 1 in Borno state? What is the extent of IDPs' safety and security needs satisfaction with interventions by SEMA in IDPs Dalori Camp 1 in Borno state? This study adopted a survey research design. With a representative sample, that is, one that is representative of the larger population of interest, one can describe the attitudes of the population from which the sample was drawn. The population of this study comprises of all registered IDPs currently settled at Dalori Camp 1 Maiduguri Borno state, with twenty-nine thousand, nine hundred and sixty-four (Borno State Emergency Management). Therefore, $1 \%$ of 29964 was used as the sample size, which is 300 . The results of the findings revealed that Majority of the IDPs are not satisfied; the quality and quantity of food, clothing and shelter provided were very low as indicated by the mean 1.07. The IDP's level of satisfaction with quality and quantity of clothing materials distributed was very low as indicated by the mean 1.91 and 7.35 of SD proved the statement negative. Recommendation were made.
\end{abstract}

Keywords: Displaced People, Emergency Management, Shelter, Intervention by Emergency Management Agency, SEMA

\section{Introduction}

Internally Displaced Persons (IDPs) have been defined in so many ways by different authorities. However, IDPs in the present context are large numbers of human population dislodged from their homes as a result of violent attacks by non-state armed group - Boko Haram. These large numbers of people were forced to leave their settlements or native homes in order to avoid or escape violence from this armed group. Being IDPs does not mean that their rights and needs as human persons should be undermined as has been the case in so many places where IDPs are found round the world.

Certain human needs are universal and the parameter of measuring its level of satisfaction varies, based on time, place and availability of resources. Evidently, people living in peaceful time and comfort zones will enjoy different levels of need satisfaction, compare to people living in a period of war and conflict. In peace time, resources are recuperated constantly, while in war time, resources deteriorate significantly. Availability of resources has direct bearing on the strata of need satisfaction, starting from the most common ones. Satisfactions that accrued from enjoying one level of need, will apparently determine how other aspects of human needs will be desired for and pursued. Thus, safety and security needs, rank next to the physiological needs, like food, clothing, and shelter according to psychological theorists like Abraham Maslow, Takuma Nishimura and Takashi Suzuki. The plight of Internally Displaced Persons could be pictured into this scenario.

Statistics from United States Agency for International Development (USAID, 2016) and United Nations Office for the Coordination of Humanitarian Affairs UNOCHA, 2015) suggests that IDPs comprise the largest group of vulnerable people in the world. Heightened awareness and monitoring of population displacement show that the numbers of IDPs increased significantly in the world since the end of the cold war in the 1990s due to intra-state armed conflicts. According to USAID (2016), globally, there are almost twice as many IDPs as the 13 million civilians classified as refugees who have crossed international frontiers. As such, the phenomenon of Internally Displaced Persons is generally a worldwide problem. Globally, the basic and foremost response to IDPs cases is the provision or erection of makeshift camps, to settle and accommodate this displaced population. This is followed by the provision of other forms of life saving relief materials. This by implication means that such human population (IDPs) will automatically become the responsibility and burden of governments and other local, regional or international humanitarian agencies, for a period usually unspecified. By extension, the IDPs only rely on what have been provided for them to survival, pending when they will go back to their normal livelihoods, thereby raising the questions of needs satisfaction.

The Boko Haram insurgency that started since 2009, has led to the displacement of huge number of human population in various communities of Borno State, Yobe State, and Adamawa State, Nigeria. Boko Haram attacks on the rural communities, forced these rural dwellers out of their homes and means of livelihood, thereby exposing them to unbearable hardship and humanitarian hazards. Their needs therefore, have been left at the mercies of government interventions, NGOs and other charitable gestures, in their new unpredicted abodes or camps.

\subsection{Statement of the Problem}

Internally displaced Persons IDPs, are usually cut off from their normal jobs, healthcare, security networks, and means of economic and social support. As a result, IDPs are enlisted as among the most vulnerable populations, often remaining in danger after they 
are displaced. The plight of IDPs in Borno State is not different. In spite of government interventions through State Emergency Management Agency (SEMA), narratives among IDPs in camps is that of pains, sorrow, displeasure, discomfort and outright dissatisfaction with relief materials provided for them. Their basic needs are seems to have not been met.

Unfortunately, according to Abraham Maslow, the physiological needs of man which include shelter, water, food, and clothing are the fundamental of man's needs in an ascending order. It means that until these basic needs are met satisfactorily, it is very difficult for man to desire for the next level of needs, which is safety and security as well as love and belongingness needs. In Dalori Camp 1 , based on a preliminary enquiry by the researcher, the IDPs are faced with the problem of insufficient food supply, poor housing units, and insufficient supply of clothing materials which are officially supposed to be the ideal interventions of SEMA. This development had automatically undermined their appreciation for adequate security and safety as well as love and belongingness needs. Many IDPs have resorted into self-help, by engaging in illicit activities that compromise their security and protection, in order to survive the hardship in the camp. Based on the foregoing, the researcher assessed the level of needs satisfaction among internally displaced persons (IDPs), with interventions by State Emergency Management Agency (SEMA) in a hierarchical order of physiological needs, safety and security needs, as well as love and belongingness needs in Dalori Camp 1, Borno State, Nigeria.

\subsection{Objectives of the Study}

The objectives of this study are to:

(1) Assess the extent of internally displaced persons' physiological needs satisfaction with interventions by SEMA in Dalori Camp 1 in Borno state.

(2) Assess the level of internally displaced persons' safety and security needs satisfaction with interventions by SEMA in Dalori Camp 1 in Borno state.

\subsection{Research Questions}

The following research questions were answered in this study;

(1) What is the extent of IDPs' physiological needs satisfaction with interventions by SEMA in Dalori IDPs Camp 1 in Borno state?

(2) What is the extent of IDPs' safety and security needs satisfaction with interventions by SEMA in IDPs Dalori Camp 1 in Borno state?

The findings of this research shall be of benefit to the:

(1) Internally Displace Person (IDPs): This study will be important in identifying the need satisfaction of IDPs with interventions by government agencies.

(2) Governments and Non-Governmental Organizations: This study will be a good source of reference for governments and NonGovernmental Organizations that provide and distribute relief materials to IDPs, so that they would be informed of IDPs level of satisfaction with relief material given and how to improve on them.

The study assessed the needs satisfaction of IDPs with interventions by SEMA in Dalori Camp 1. The variables covered in the study were the needs satisfaction with food and clothing interventions, need satisfaction with shelter interventions which represented the physiological needs and needs satisfaction with security and protection interventions, as well as IDPs' love and belongingness needs satisfaction. Only registered IDPs in Dalori Camp 1 were studied.

\section{Review of Related Literature}

\section{IDPs' Physiological Needs Satisfaction with Interventions in the Camps}

According to Jelili and Olanrewaju (2016) food is one of the most essential needs of an average displaced population. The level of satisfaction IDPs received from the quality and quantity of food supply to them will determine their response to other desiring needs. IDPs can manage with any kind of shelter provided to them but when it comes to food there is no alternative. However, in spite of the essentiality of food to the survival of IDPs in the camp, its supply has not been sufficient.

Data collected by International Non-Governmental Organizations Forum in Nigeria (INGOs 2015) shows that in Borno state, IDPs identified food as their most undermined needs in terms of satisfaction. The report shows that in at least 90\% of IDP households, acknowledged that most of the food relief they get, were barely satisfactory, with regard to quality and quantity. More than $44 \%$ of respondents according to the INGOs (2015) report maintain that they had just one week's worth of food remaining, and less than $20 \%$ had received food aid with nutritional values. IDPs request food assistance (in kind or cash/vouchers) or livelihood support to make money themselves. The INGOs (2015) further revealed that $60 \%$ of the IDPs in camps and host communities are not eating adequately nutritious foods. An empirical study conducted by Hines and Balletto (2012) revealed that the major dilemma in situations of displacement is ensuring that humanitarian assistance, in particular food aid, reaches the most vulnerable and has the greatest impact while adhering to basic principles of neutrality and impartiality. In Borno there have cases of food diversion or shortchanges to destinations other than the camps they were meant for. According to Hines and Balletto (2012), even when the food is supplied to the IDPs its nutritional composition has continued to be a source of concern.

According to Osagioduwa and Oluwakorede (2016) foods supplies to IDPs were largely of carbohydrate content, which often impose problem of nutritional needs among the IDPs. Malnutrition is a serious problem for the displaced population, especially 
children and nursing mothers. Malnutrition rates in Borno and Yobe States remain high. A Standardized Monitoring and Assessment Relief and Transition (SMART) Survey conducted by the federal government of Nigeria with UNICEF in spring 2014, found General Acute Malnutrition (GAM) in Yobe State to be $15.5 \%$ and $13.6 \%$ in Borno state. A needs assessment to the Diffa Region of Niger noted reports of increased admissions in health centers for malnutrition - thought to be attributable to refugees and returnees from northeastern Nigeria. There are several reports that most health facilities in conflict affected areas are closed, limiting the available assistance for malnourished children (UNOCHA, 2015). More so, according to Humanitarian Needs Overview (HNO) Nigeria (2015) report, an estimated $90 \%$ of IDPs are staying with host communities and most are dependent on host families for food. The already limited resources of host families are now under serious strain posing a precarious food security and nutrition. Both in host communities and in the camps, IDPs have started engaging in limited commercial activities, selling basic goods in small quantities to get income to meet household needs especially for food. Most IDPs are therefore facing food insecurity, mainly as a result poor access to food due to loss of own agricultural production and other off season means of livelihoods.

UNICEF in collaboration with Nigerian government and other partners is supporting Community-based Management of Acute Malnutrition (CMAM) in 11 northern states including Borno, Yobe and Adamawa states. These interventions include provision of Vitamin A supplementation and iron-folate, anthelminthic drug. CMAM services also include counseling on exclusive breast feeding and appropriate complementary feeding for infants and young children. Through the CMAM centers, UNICEF provided treatment to a caseload of 106,122 children with severe acute malnutrition in Borno (45,694 children), Yobe (34,337 children) and Adamawa (26,091 children) respectively (UNOCHA, 2015).

Kindra (2015) noted that the conflict in the Northeast has already spurred worrying malnutrition indicators in the region. IPC food insecurity is presently expected to be at either crisis or stressed levels throughout Borno and Yobe, with households in IDP camps struggling to meet their basic needs. Escalating insecurity is limiting access into the region, thereby impacting the availability of food; farmers are abandoning farms in fear of attacks, thereby lowering agricultural production. This has therefore translated into the scarcity of quality food supply in various camps in Borno state. In Bama town, Borno, $15 \%$ of children were found to have Severe Acute Malnutrition (SAM). High levels of mortality - at least 188 deaths in June, mostly from malnutrition or diarrhoea have also been reported (Famine Early Warning System Network (FEWSNET), 2016; AFP, 2016; MSF, 2016). In Banki, Bama LGA, deaths due to starvation or malnutrition have been reported, mainly among children and the elderly. Three/four people are dying every day. At least 80 children have been reported with SAM (UNOCHA, 2016). In Monguno LGA, GAM was found to be $32 \%$ and SAM 13\%. In nearby Dikwa LGA, high levels of acute malnutrition were identified in April. As of 15 June, in Muna IDP camp, near Maiduguri, GAM was at 29\% and SAM 6\% (FEWSNET, 2016). SAM has been reported among IDPs arriving in Maiduguri from Mafa LGA, Borno (AFP, 2016).

Nevertheless, Imasuen (2015) shows the effect of government response, however fails the test at the 5\% level and therefore indicate that the food aid responses by government do not have significant impact on the humanitarian crises at the Shuwa camp. The results further revealed that in Tingo Camp the effect of government response on food supplies of the IDPs fails the test at the 5\% level and therefore indicate that the responses by government do not have significant impact on the humanitarian crises at the Tingo camp.

Furthermore, an ethnographic study by Abdulazeez (2014) observed that the government is supposed to provide the basic needs of the IDPs including food. Based on her study some camps are lucky enough to have government-employed cooks, but it was not the case in the NYSC camp Maiduguri: displaced women were organized into cooks. According to her findings, Government officials (SEMA) say they feed displaced people three times a day with assorted nutritional meals. But in reality people are usually fed only once in a day and they eat the same things every day. This is against the backdrop that other international organizations like World Food Programme claimed to have intervened alongside the government to improve food supplies to the IDPs. This therefore suggests that there could be some level of technical vis-à-vis financial incapacitations that affect adequate food for the IDPs.

Hines and Balletto (2012) empirical work further noted that even though the application of the methodology developed by WFP and its partners is still in progress, a number of interesting observations and lessons are shared. Initial findings have allowed WFP to better understand when food assistance is required, i.e., the crucial period after the first three months of displacement. This period has been largely forgotten and many activities were not designed to reach those most in need during this time. As a result, in the next phase of WFP's operation more attention will be given to this crucial period and to balancing direct feeding requirements through soup kitchens with livelihood support. A good understand of the technical implications of food distribution by government and other intervention agencies will aid the sufficient and satisfactory distribution of foods to the IDPs.

On the other hand, the haste at which IDPs often left their homes, have never permitted them to take good number of cloths. Many of the IDPs rushed out of their homes in the middle of the night, thus, are only clothed with the cloth they were wearing before their displacement (UNOCHA, 2012). Even when they took some cloth with them it is not sufficient enough to take them throughout the unspecific period they will stay in the camps (IRIN, 2013); resulting into most of the IDPs been clothed in tattered or worn out cloths. Most reports and literature on IDPs speak little or nothing about clothing (Love Word 2012). The scantiness of clothing as one of the essential relief of IDPs as contained in available literatures suggest that clothing of IDPs occupy a very insignificant rung in the need satisfactions of IDPs. Clothing as relief material of IDPs are rather encapsulated into what is generally referred to as "non-food" materials. 
However, government of Borno State through SEMA together with other humanitarian agencies has made several efforts in providing IDPs with clothing materials. However, the level of satisfactions IDPs received from the clothing materials provided has demarcated the feelings of individual IDPs as various survey indicated. According to Samaritaran International (2013) survey on five IDPs camps in Maiduguri, over 56\% of the IDPs expressed displeasure with the quality of cloth provided for them during the extreme cold weather. From the report, only a handful of IDPs (35\%) received adequate clothing to match with the extreme cold weather. It is therefore noteworthy that the weather condition constitutes one of the dire factors that further complicate IDPs satisfaction with clothing. In the event the IDPs were displaced during the hot season, they often arrived the camps with light dress, which apparently is not adequate for them to survive the extreme cold weather. As such, the need for cardigans and sweaters will be eminent among the IDPs in camps. Unfortunately, such clothing materials are not ready provided for IDPs in camps, leading to search for cash in order for them to get it in open market (United Nations High Commissioner for Refugees (UNHCR, 2014). In an empirical study Imasuen (2015) carried out in three sampled IDP camps (NYSC, Tingo and Shuwa), indicated that $89 \%$ of the respondents barely get a suitable cloth for the cold weather.

\subsection{IDPs' Safety and Security Needs Satisfaction with Interventions in the Camps}

According to Borton, Buchanan-Smith and Otto (2005), first and foremost, responsibility for assisting and protecting IDPs lies with the national authorities. This is against the background that there is no international law that streamlined how IDPs should be secured. Thus, it falls within the orbit of national security architecture of concerned country to secure and protect IDPs. In Borno state, the security of the IDPs in camps has been a collective responsibility of national security agencies and some youth volunteer groups. The Nigerian Police and Nigerian Army have played significant role in this regard. However, the overall security and protection design of IDPs are concentrated in Guiding Principles on IDP also referred to as national IDP policy, which is a domesticated version of Kampala Convention. Nevertheless, the legislation and enforcement of national IDPs policy in Borno state have leave little or nothing to be celebrated in IDPs camps.

Borton, Buchanan-Smith and Otto (2005) further observed that where national government has incorporated the Guiding Principles into national legislation, the prospects for protecting IDPs are greatest, at least in theory. The particular challenge is that, in many cases, the state authorities are the authors of the displacement, and may not have the political will and/or capacity and resources to assist and protect this particular group of displaced citizens. According to Slim and Eguren (2004):

People are not protected just because the law says that they are and because it identifies authorities with a duty to protect. In many wars, laws are frequently broken consciously and purposively by all sides.

In turn, one of the consequences of displacement is usually the breakdown of community structures and hence traditional forms of protection. This leaves IDPs even more vulnerable to abuse and to violence.

Nonetheless, how to provide protection, and even more fundamentally, what protection means in practice, are challenges that have exercised humanitarian agencies in recent years, not least as so many now espouse a rights-based approach to their work, yet face a formidable task in making this transition from being solely service-providers. In relation to IDPs, protection issues are often starkest, but it is also an issue for other population groups which have not been displaced but are still threatened by violence and abuse. According to the Inter-Agency Standing Committee Internally Displaced Persons Protection Policy (1999), protection is defined as "... all activities aimed at obtaining full respect for the rights of the individual in accordance with the letter and the spirit of the relevant bodies of law (i.e. human rights law, international humanitarian Law, refugee law). Protection therefore involves creating an environment conducive to respect for human beings, preventing and/or alleviating the immediate effects of a specific pattern of abuse, and restoring dignified conditions of life through reparation, restitution and rehabilitation. In the opinion of Slim and Eguren (2004) protection is "the challenge of making states and individuals meet their humanitarian responsibilities to protect people in war and filling-in for them as much as possible when they do not".

Thus, in contrast to the provision of material assistance, protection work is multi-faceted. All in all it has implications for how humanitarian interventions are provided, in ways that minimize vulnerable people's risks to new or further violation. As far as possible, protection work should involve the people in need of protection themselves (Slim and Eguren, 2004). Taking on board the legal dimension of protection work, the sensitive advocacy that may be required, as well as the logistical challenges of delivering life-saving aid in insecure environments have stretched the skills and resources of many humanitarian agencies.

Protection can be divided into three sub-layers, which include mental health and psychosocial support, child protection and sexual and gender-based violence. Mental health as the name implies deals with clinical psychiatric care. According to International Federation of Red Cross and Red Crescent Societies (2014) the need for psychosocial support is growing as the affected people need support to help them recover from the loss of their family members, injuries, damage to property, displacements, family separation and loss of livelihoods. It is estimated that 2.15 million men, women, girls and boys facing physical and psychological trauma related to the insurgency in North-east Nigeria (Humanitarian Overview 2015). Child protection has been among the top burners in his regard.

The Child Protection has five major response priorities, which include: Unaccompanied and separated children (UAC/SC), Child labor, Child soldiers, Violence against children, and Children in trouble with the law. 
Child protection in all ramifications is aimed at building the capacity of intervention partners to protect children's welfare, to mainstream child protection into the broader humanitarian response, to prevent abuses, to provide at-risk children with safe spaces for disclosure, and to refer at-risk children to the appropriate venues for assistance (Shteiwi, Walsh, and Klassen 2014). It is a known fact that Borno State and Local Government Area authorities are struggling to meet the needs of both children in their community and the needs of displaced children.

\section{Methodology}

This study adopted a survey research design. A survey research is used to assess thoughts, opinions, and feelings which consist of a predetermined set of questions that is given to a sample. With a representative sample, that is, one that is representative of the larger population of interest, one can describe the attitudes of the population from which the sample was drawn. A good sample selection is a key as it allows one to generalize the findings from the sample to the population, which is the whole purpose of survey research

The population of this study comprises of all registered IDPs currently settled at Dalori Camp 1 Maiduguri Borno state, with twentynine thousand, nine hundred and sixty four (Borno State Emergency Management. Therefore, 1\% of 29964 was used as the sample size, which is 300 .

Proportionate sampling procedure was used to assigned questionnaires to each Local Government Areas, while systematic sampling techniques of $10^{\text {th }}$ number was used to select respondents.

The research instrument that was used to collect data for this study was a self developed questionnaire on Needs Satisfaction of Internally Displaced Persons with Intervention (NSIDP). The questionnaire was divided into three (3) sections; A on demographics information; section B was on physiological needs of IDP's (food clothing and shelter) Provided; section C on IDP's safety and security. The modified Likert scale of response mode of high extent; moderate extent and low extent with scores of 3, 2 and 1 respectively was employed. Copies of the drafted questionnaire were given to 3 experts in the Department of Continuing Education and Extension Services, University of Maiduguri for relevant inputs. This has helped in improving the quality of the instrument for data collection. The content and face validity of the instrument was determined by the research experts in Department of Continuing Education and Extension Services, University of Maiduguri. Data collected was subjected to statistical test using Spearman Brown prophecy formula to determine the reliability index $=0.81$.

The researcher give the permission letter to manager SEMA Dalori IDP Camp 1 manager, through GOC 7 Division Nigerian Army Garrison Maiduguri, who in return provides all the necessary assistance to the researcher for the administration of questionnaires. Three hundred questionnaires were administered and retrieved for data analysis in five days.

The data collected for this study were analysed using descriptive statistics of frequency count, percentage, mean, and standard deviation to explain the demographic characteristics of the respondents and to answer the research questions. 


\section{Results}

Table 1: IDP's Level of Satisfaction with Physiological Needs (Food, Clothing, Shelter) Provided

\begin{tabular}{|c|c|c|c|c|c|c|c|}
\hline S/No & Items / Variables & $\begin{array}{l}\text { HE } \\
(\%)\end{array}$ & $\begin{array}{l}\text { ME } \\
(\%)\end{array}$ & $\begin{array}{l}\mathbf{L E} \\
(\%)\end{array}$ & Total & Mean & SD \\
\hline 1. & $\begin{array}{l}\text { I am satisfied with the taste of the food prepared in the } \\
\text { camp }\end{array}$ & $\begin{array}{c}5 \\
(15)\end{array}$ & $\begin{array}{c}16 \\
(32)\end{array}$ & $\begin{array}{c}279 \\
(279)\end{array}$ & 300 & 1.09 & 0.08 \\
\hline 2 & I am satisfied with the nutritional value of the camp food & $\begin{array}{c}2 \\
(6)\end{array}$ & $\begin{array}{c}43 \\
(86)\end{array}$ & $\begin{array}{c}255 \\
(255)\end{array}$ & 300 & 1.16 & 0.10 \\
\hline 3 & I am satisfied with the rationing of the camp food & $\begin{array}{c}2 \\
(6)\end{array}$ & $\begin{array}{c}11 \\
(22)\end{array}$ & $\begin{array}{c}287 \\
(287)\end{array}$ & 300 & 1.05 & 0.07 \\
\hline 4 & $\begin{array}{l}\text { I am satisfied with the quantity of meat (beef) or other } \\
\text { poultry products (chicken or eggs) serve in the camp }\end{array}$ & $\begin{array}{c}0 \\
(0)\end{array}$ & $\begin{array}{c}3 \\
(6)\end{array}$ & $\begin{array}{c}297 \\
(297)\end{array}$ & 300 & 1.01 & 0.05 \\
\hline 5 & $\begin{array}{l}\text { I am satisfied quality and quantity of raw food supply in } \\
\text { the camp }\end{array}$ & $\begin{array}{l}3 \\
(9)\end{array}$ & $\begin{array}{c}6 \\
(12)\end{array}$ & $\begin{array}{c}291 \\
(291)\end{array}$ & 300 & 1.04 & 0.05 \\
\hline 6 & $\begin{array}{l}\text { I am satisfied with the ingredients provided for the } \\
\text { cooking of raw food }\end{array}$ & $\begin{array}{c}1 \\
(3)\end{array}$ & $\begin{array}{c}3 \\
(6) \\
\end{array}$ & $\begin{array}{c}296 \\
(296) \\
\end{array}$ & 300 & 1.02 & 0.03 \\
\hline \multirow[t]{2}{*}{7} & I am satisfied with the aroma of the camp food & $\begin{array}{c}2 \\
(6)\end{array}$ & $\begin{array}{c}14 \\
(28)\end{array}$ & $\begin{array}{c}284 \\
(284) \\
\end{array}$ & 300 & 1.06 & 0.03 \\
\hline & Mean & & & & & 1.06 & 0.41 \\
\hline 8 & $\begin{array}{l}\text { I am satisfied with quality of clothing materials provided } \\
\text { in the camp }\end{array}$ & $\begin{array}{c}0 \\
(0)\end{array}$ & $\begin{array}{c}2 \\
(4)\end{array}$ & $\begin{array}{c}298 \\
(298)\end{array}$ & 300 & 1.01 & 0.39 \\
\hline 9 & $\begin{array}{l}\text { I am satisfied with the quantity of clothing material } \\
\text { provided in the camp }\end{array}$ & $\begin{array}{c}0 \\
(0)\end{array}$ & $\begin{array}{c}3 \\
(6) \\
\end{array}$ & $\begin{array}{c}297 \\
(296) \\
\end{array}$ & 300 & 1.01 & 0.43 \\
\hline 10 & $\begin{array}{l}\text { I am satisfied with the size(s) of the cloth provided in the } \\
\text { camp }\end{array}$ & $\begin{array}{c}0 \\
(0)\end{array}$ & $\begin{array}{c}2 \\
(4)\end{array}$ & $\begin{array}{c}298 \\
(298)\end{array}$ & 300 & 1.01 & 0.25 \\
\hline 11 & $\begin{array}{l}\text { I am satisfied with colour(s) of the clothing materials } \\
\text { provided in the camp }\end{array}$ & $\begin{array}{c}0 \\
(0)\end{array}$ & $\begin{array}{c}2 \\
(4)\end{array}$ & $\begin{array}{c}298 \\
(298)\end{array}$ & 300 & 1.01 & 0.41 \\
\hline 12 & $\begin{array}{l}\text { I am satisfied with the type of cloth provided in the camp } \\
\text { during extreme cold weather }\end{array}$ & $\begin{array}{c}0 \\
(0)\end{array}$ & $\begin{array}{c}0 \\
(0)\end{array}$ & $\begin{array}{c}300 \\
(300)\end{array}$ & 300 & 1.00 & 0.38 \\
\hline \multirow[t]{2}{*}{13} & $\begin{array}{l}\text { I am satisfied with the style of the sewing of the materials } \\
\text { provided in the camp }\end{array}$ & $\begin{array}{c}0 \\
(0) \\
\end{array}$ & $\begin{array}{c}1 \\
(2)\end{array}$ & $\begin{array}{c}299 \\
(299) \\
\end{array}$ & 300 & 1.00 & 0.47 \\
\hline & Mean & & & & & 1.01 & \\
\hline 14 & I am satisfied with the roofing in the camp & $\begin{array}{c}109 \\
(327)\end{array}$ & $\begin{array}{c}154 \\
(308) \\
\end{array}$ & $\begin{array}{c}37 \\
(37) \\
\end{array}$ & 300 & 2.24 & 1.03 \\
\hline 15 & I am satisfied with the spacing available in the camp & $\begin{array}{c}23 \\
(69)\end{array}$ & $\begin{array}{c}41 \\
(82)\end{array}$ & $\begin{array}{c}236 \\
(236)\end{array}$ & 300 & 1.29 & 0.31 \\
\hline 16 & I am satisfied with the level of sanitation of the shelter & $\begin{array}{c}116 \\
(384)\end{array}$ & $\begin{array}{c}66 \\
(132)\end{array}$ & $\begin{array}{c}118 \\
(118) \\
\end{array}$ & 300 & 1.99 & 1.08 \\
\hline 17 & I am satisfied with the level of privacy in the camp shelter & $\begin{array}{c}21 \\
(63) \\
\end{array}$ & $\begin{array}{c}83 \\
(166) \\
\end{array}$ & $\begin{array}{c}196 \\
(196)\end{array}$ & 300 & 1.41 & 0.42 \\
\hline 18 & $\begin{array}{l}\text { I am satisfied with the cross ventilation of the camp } \\
\text { shelter }\end{array}$ & $\begin{array}{c}20 \\
(60)\end{array}$ & $\begin{array}{c}78 \\
(156) \\
\end{array}$ & $\begin{array}{c}202 \\
(202)\end{array}$ & 300 & 1.39 & 0.68 \\
\hline 19 & I am satisfied with the floor of the camp shelter & $\begin{array}{c}2 \\
(6) \\
\end{array}$ & $\begin{array}{c}21 \\
(42)\end{array}$ & $\begin{array}{c}277 \\
(277) \\
\end{array}$ & 300 & 1.08 & 0.63 \\
\hline 20 & $\begin{array}{l}\text { I am satisfied with quietness and safety of the camp } \\
\text { shelter }\end{array}$ & $\begin{array}{c}56 \\
(168) \\
\end{array}$ & $\begin{array}{c}117 \\
(234) \\
\end{array}$ & $\begin{array}{c}127 \\
(127) \\
\end{array}$ & 300 & 1.76 & 0.84 \\
\hline \multirow[t]{2}{*}{21} & $\begin{array}{l}\text { I am satisfied with the mattress provided in the camp } \\
\text { shelter }\end{array}$ & $\begin{array}{c}0 \\
(0)\end{array}$ & $\begin{array}{c}0 \\
(0)\end{array}$ & $\begin{array}{c}300 \\
(300)\end{array}$ & 300 & 1 & 0.42 \\
\hline & Mean & & & & & 1.52 & \\
\hline
\end{tabular}

\section{Source: Field Survey 2018}

Table, which is on IDP's level of satisfaction with quality and quantity of food provided in the camp, revealed that 5 (15) of the respondents had high extent of food prepared in the camp, sixteen 16 (32) of the respondents had moderate extent, while 279 (279) of the respondents had low extent of the food prepared in the camp. The table also revealed that 2 (6) of the respondents had high extent of nutritional value of the camp food, 43 (86) of the respondents had moderate extent, while 255 (255) of the respondents had low extent of the nutritional value of the camp food. Similarly, the table also revealed that 2 (6) of the respondents had high 
extent satisfaction with the rationing of food in the camp, 11 (22) of the respondents had moderate extent satisfaction, while 287 (287) of the respondents had low extent satisfaction with the rationing of food in the camp. Also, the table revealed that none of the respondents had high extent satisfaction with the quantity of meat (beef) or other poultry products (chicken or eggs) serve in the camp, 3 (6) of the respondents had moderate extent satisfaction, while 297 (297) of the respondents had low extent satisfied with the quantity of meat (beef) or other poultry products (chicken or eggs) serve in the camp. 3 (9) of the respondents satisfied with the quality and quantity of raw food supply in the camp, 6 (12) of the respondents (6) had moderate extent satisfaction, while 291 (291) of the respondents had low extent satisfaction with the quality and quantity of raw food supply in the camp. The item 6 of the table further revealed that 1 (3) of the respondents had high extent satisfaction with the ingredients provided for the cooking of raw food in the camp, $3(6 \%)$ of the respondents had moderate extent, and 296 (296) of the respondents had low extent satisfaction with the ingredients provided for the cooking of raw food in the camp. The table finally revealed that $2(6)$ of the respondents had high extent satisfaction with the aroma of the camp food, 14 (28) of the respondent had moderate extent satisfaction, while 284 (284) of the respondents had low extent satisfaction with the aroma of the camp food. The table showed that all items are below 2.0.The aggregate mean of 1.07 and 0.41 of SD proved the statement negative. This proved that level of IDPs' Physiological Needs Satisfaction with Interventions by SEMA is low.

Table 2: IDPs Level of Satisfaction with Protection and Security Provided

\begin{tabular}{|c|c|c|c|c|c|c|c|}
\hline S/No & Items / Variables & $\begin{array}{l}\text { HE } \\
(\%)\end{array}$ & $\begin{array}{l}\text { ME } \\
(\%)\end{array}$ & $\begin{array}{l}\text { LE } \\
(\%)\end{array}$ & Total & Mean & SD \\
\hline 1 & I am satisfied with the parameter fencing in the camp & $\begin{array}{c}13 \\
(39)\end{array}$ & $\begin{array}{c}101 \\
(202)\end{array}$ & $\begin{array}{c}186 \\
(186)\end{array}$ & 300 & 1.42 & 0.74 \\
\hline 2 & $\begin{array}{l}\text { I am satisfied with the deployment of security operatives } \\
\text { in the camp }\end{array}$ & $\begin{array}{c}118 \\
(354)\end{array}$ & $\begin{array}{c}123 \\
(246)\end{array}$ & $\begin{array}{c}59 \\
(59)\end{array}$ & 300 & 2.19 & 0.84 \\
\hline 3 & I am satisfied with the conduct of the security operatives & $\begin{array}{c}99 \\
(297)\end{array}$ & $\begin{array}{c}114 \\
(228)\end{array}$ & $\begin{array}{c}87 \\
(87)\end{array}$ & 300 & 2.04 & 0.79 \\
\hline 4 & $\begin{array}{l}\text { I am satisfied with the level of screening of visitors in } \\
\text { the camp }\end{array}$ & $\begin{array}{c}78 \\
(234)\end{array}$ & $\begin{array}{c}93 \\
(186)\end{array}$ & $\begin{array}{c}129 \\
(129)\end{array}$ & 300 & 1.83 & 0.38 \\
\hline 5 & I am satisfied with the level of assess control in the camp & $\begin{array}{c}56 \\
(168)\end{array}$ & $\begin{array}{c}67 \\
(134)\end{array}$ & $\begin{array}{c}177 \\
(177)\end{array}$ & 300 & 1.59 & 0.02 \\
\hline 6 & $\begin{array}{l}\text { I am satisfied with the level of counseling and socio- } \\
\text { psychological support in the camp }\end{array}$ & $\begin{array}{c}2 \\
(6)\end{array}$ & $\begin{array}{c}16 \\
(32)\end{array}$ & $\begin{array}{c}282 \\
(282)\end{array}$ & 300 & 1.06 & 0.69 \\
\hline 7 & $\begin{array}{l}\text { I am satisfied with manner in which cases of rape and } \\
\text { other gender based violence are handled in the camp }\end{array}$ & $\begin{array}{c}4 \\
(12)\end{array}$ & $\begin{array}{c}26 \\
(52)\end{array}$ & $\begin{array}{c}270 \\
(270)\end{array}$ & 300 & 1.11 & 0.30 \\
\hline & Mean & & & & & 1.61 & 3.76 \\
\hline
\end{tabular}

Source: Field Survey 2018 • Key: HE = High Extent, ME = Moderate Extent, LE = Low Extent

Table, which is on IDPs level of satisfaction with protection and security provided, showed that 13 (39) of respondents had high extent satisfaction with the parameter fencing in the camp, 101 (202) had moderate extent, while 186 (186) of the respondents had low extent satisfaction with the parameter fencing in the camp. 118 (354) of the respondents had high extent satisfaction with the deployment of security operatives in the camp, 123 (246) had moderate extent, while 59 (59) of the respondents had low extent satisfaction with the deployment of security operatives in the camp. Also, 99 (297) of the respondents had high extent satisfaction with the conduct of the security operatives, 114 (228) had moderate extent, while 87 (87) of the respondents had low extent satisfaction with the conduct of the security operatives. The table further revealed that 78 (234) of the respondents had high extent satisfaction with the level of screening of visitors in the camp, 93 (186) had moderate extent, while 129 (129) of the respondents had low extent satisfaction with the level of screening of visitors in the camp. The table also showed that 56 (168) of the respondents had high satisfaction with the level of assess control in the camp, 67 (134) had moderate extent, while 177 (177) of the respondents had low extent satisfaction with satisfied with the level of assess control in the camp. Similarly, 2 (6) of the respondents had high satisfaction with the level of counseling and socio-psychological support in the camp, 16 (32) had moderate extent, while 282 (282) of the respondents had low extent satisfaction with the level of counseling and socio-psychological support in the camp. 4 (12) of the respondents had high extent satisfaction with the manner in which cases of rape and other gender based violence are handled in the camp, 26 (52) had moderate extent, while 270 (270) of the respondents had low extent satisfaction with the manner in which cases of rape and other gender based violence are handled in the camp. The table shows that all items are below 2.0 while items 2 and 3 are above constant mean of 2.0. The aggregate mean of 1.61 and 3.76 of SD proved the statement negative. This proved that level of IDPs' Safety and Security Needs Satisfaction with SEMA Interventions is low

\section{Summary of Finding}

The following are the summary of findings:

(1) Majority of the IDPs level of satisfaction with quality and quantity of food, clothing and shelter provided was very low as indicated by the mean 1.07.

(2) The IDP's level of satisfaction with quality and quantity of clothing materials distributed was very low as indicated by the mean 1.91 and 7.35 of SD proved the statement negative. 


\subsection{Discussions}

The result above revealed that majority of the IDPs level of satisfaction with quality and quantity of food, clothing and shelter provided were very low. This finding is in line with the findings of Jelili and Olanrewaju (2016) who found that food is one of the most essential needs of an average displaced population. The level of satisfaction IDPs received from the quality and quantity of food supply to them will determine their response to other desiring needs.

The result also concurred with the study conducted by Hines and Balletto (2012) who revealed that the major dilemma in situations of displacement is ensuring that humanitarian assistance, in particular food aid, reaches the most vulnerable and has the greatest impact while adhering to basic principles of neutrality and impartiality.

The findings also agreed with the finding of Osagioduwa and Oluwakorede (2016) who discovered that foods supplies to IDPs were largely of carbohydrate content, which often impose problem of nutritional needs among the IDPs. Malnutrition is a serious problem for the displaced population, especially children and nursing mothers.

\subsection{Summary}

The main purpose of this study was to assess the level of need satisfaction of IDPs in Dalori camp1 Maiduguri Borno State received from interventions from SEMA. The study was guided by three objectives and three research questions. The variables covered in this respect include the IDPs' physiological needs satisfaction, under which food, clothing and shelter were examined. Second one was the IDPs' security and safety needs satisfaction, while the third objective was the IDPs' love and belongingness needs satisfaction.

\section{Conclusion}

Based on the findings of the study, it was concluded that the level of satisfaction among IDPs in terms of quality and quantity of food, shelter and clothing provided, protection and security provided and also the love and belongingness needs were found to be very low. Thus, any shortage or inadequacies in government interventions will totally affect the existence of the IDPs in camps.

\section{References}

[1] Borton J., Buchanan-Smith M., Otto R. (2005). Support to Internally Displaced Persons - Learning from Evaluations. Synthesis Report of a Joint Evaluation Programme. London: Sida

[2] Hines D., Balletto R. (2002). Assessment of Needs of Internally Displaced Persons in Colombia. Overseas Development Institute London

[3] Human Right Watch. (2015). Like We Are Not Nepali: Protest and Police Crackdown in the Tera Region of Nepal, October 2015

[4] Imasuen E. (2015). Insurgency and humanitarian crises in Northern Nigeria: The case of Boko Haram, African Journal of Political Science and International Relations, 9 (7), July, 2015

[5] USAID. (2012). Assistance to Internally Displaced Persons Policy Implementation Guidelines. Internal USAID Document

[6] World Food Programme (WFP). Forced To Make Deeper Cuts in Food Assistance for Syrian Refugees Due To Lack Of Funding, Report. 1 July 2015

[7] RIN. Fuel shortage threatens Nepal aid as winter comes. 12 October 2015

[8] Rotimi O. (2015). Strategies for Rehabilitating IDPs in Nigeria, Lagos

[9] Rotimi O. (2015). IDPs in Nigeria and Call for Urgent Intervention. Premium Times December 28, 2015

[10] Sambo M. (2013). Influence of Maslow's Hierarchy of Needs Theory in a Displaced Population. Journal of Contemporary, 5

[11] Shteiwi M., Walsh J., Klassen C. (2014). Coping with the Crisis - A Review of the Response to Syrian Refugees in Jordan, Center for Strategic Studies, Jordan

[12] Slim H., Eguren L. E. (2004), Humanitarian protection. A guidance booklet, ALNAP

[13] Tukur M. D., Fausat A. F. (2015). Effects of Insurgency on Borno State, Journal of Economics and Sustainable Development, 6 (16), 2015

[14] United Nations Office for the Coordination of Humanitarian Affairs (UNOCHA). (26 March 2015). Nigeria: Humanitarian Needs Overview 